\title{
Whither (reason and science in) America?
}

Reasoned, skeptical debate is the lifeblood of science. Its practitioners necessarily sit at the same table with others who disagree with them. This cannot be said of political discourse in America today.

As Nature Methods goes to press, the presidential debates leading up to the 2016 United States election are in full swing. Notably absent during this process is any, well, debate. Instead the American public is treated to a series of accusatory thrusts and parries that say more about the personas of candidates Hillary Clinton and Donald Trump than about their policies.

The candidates are barely comparable in their knowledge of the issues, whether of climate change, health care, economics or foreign affairs. Clinton is invariably well informed and is an experienced actor on the world stage; Trump is neither. And while the dearth of substantial debate between them is in part due to the disparity in their knowledge, it also reflects the debate-shielded isolation in which many citizens now habitually live. Indeed, the practice of discussion with people with whom one disagrees seems to have gone out of the repertoire of many, irrespective of political leaning, in recent times.

Right-wing radio hosts fume, smirk and thunder at an audience already convinced of their positions. Leftleaning websites are read almost exclusively by those already fundamentally sympathetic to their views. Dissent, on the internet, is typically expressed in the swamp of the comments section or on Twitter. The Republican-controlled US Senate refuses to even hear the arguments in favor of an eminently qualified Democratic nominee to the Supreme Court. The muscle of reasoned argument in America has gone flabby. As the author of a recent piece in The New Yorker magazine put it, we do not argue, we "serially fulminate."

The situation in science is very different. Scientific discourse is a constant, collective process of challenge and argument, in which no scientist can afford not to participate. Scientists must, and do, talk to the people who disagree with them; they furthermore must, and most often do, attempt to convince their interlocutors with argument-supported by evidence - rather than by shouting louder or accusing harder. There is much justifiable criticism that can be levied at the scientific process, including at peer review. But, warts and all, this process is still mainly an example of people at their best. There would be much to gain were politicians and citizens to adopt some of its strengths, wishful though this sort of thinking may sound in the present climate.
Clearly politics and science do not map perfectly onto each other. Science has a relatively clear goal, the discovery or understanding of some aspect of the natural or physical world. Politics encompasses a vast range of goals, which typically vary for different groups and often are mutually incompatible. Nevertheless, all debate, scientific or otherwise, demands a common understanding of what constitutes a fact. A shared approach to facts, plus a desire to understand the world as it actually is and not as the scientist wishes it to be, drives scientific progress despite (indeed, because of) the near-constant debate between scientists. But facts are treated very differently in the national political discussion.

Trump is well known for his blithe dismissal of inconvenient facts, but he is certainly not the only or even the most egregious instance of this irresponsible and frequently dangerous attitude. Famously, a senior aide to former Republican president George W. Bush told a reporter that "reality-based" thinking is not relevant any more, an approach that surely informed the disastrous invasion of Iraq. In scientific matters, perhaps the best example is the denial of the evidence for human-induced climate change, accepted even among ever-skeptical scientists, by more than a few elected Republican officials.

The 2016 US election will produce vastly different outcomes depending on which party wins the presidency and the legislature. When it comes to science, the platforms of the two presidential candidates are starkly different too. Clinton, in her speech at the Democratic convention, signaled her support for and belief in science. Her platform promises funding for several areas of biomedical research, particularly within neurobiology, and outlines an approach, including technology development, to address climate change. Trump does not even mention biomedical research or climate change in his campaign literature. But beyond the ideological and policy differences between the two parties, the very role of reason in the national discourse, already eroded, seems to hang in the balance.

We urge our readers to inject a dose of their natural scientific skepticism and openness to debate even outside their professional sphere. And to our American readers, especially those in swing states, we exhort you to vote! 